\title{
Resistance profile to antimicrobials agents in methicillin-resistant Staphylococcus aureus isolated from hospitals in South Brazil between 2014-2019
}

\author{
Adriana Medianeira Rossato ${ }^{[1]}$, Muriel Primon-Barros ${ }^{[1]}$, Lisiane da Luz Rocha ${ }^{[1]}$, \\ Keli Cristine Reiter ${ }^{[1]}$, Cícero Armídio Gomes Dias ${ }^{[1]}$ and Pedro Alves d'Azevedo ${ }^{[1]}$
}

[1]. Universidade Federal de Ciências da Saúde de Porto Alegre, Programa de Pós-graduação em Ciências da Saúde, Porto Alegre, RS, Brasil.

\begin{abstract}
Introduction: Methicillin-resistant Staphylococcus aureus (MRSA) is a common pathogen causing healthcare-associated infections. Owing to the restricted use of beta-lactams in MRSA infections, non-beta-lactam antimicrobials are required for treatment. However, MRSA can develop resistance mechanisms to non-beta-lactam antimicrobials, which reduces viable treatment options. Here, we evaluated the antimicrobial susceptibility and resistance genes of MRSA isolated from hospitalized patients in South Brazil. Methods: The antimicrobial susceptibilities of hospital MRSA(217) isolates were determined by disk diffusion or microdilution methods. Additionally, the presence of 14 resistance genes and SCCmec typing was performed by PCR. Results: Among the antimicrobials tested, we observed high erythromycin (74.2\%), ciprofloxacin (64.5\%), and clindamycin (46.1\%) resistance rates and complete susceptibility to linezolid and vancomycin. Seventeen different patterns of MRSA antimicrobial resistance were observed, of which $42.9 \%$ represented multidrug resistance. Among erythromycin-resistant MRSA, 53.4\%, 45.3\%, 37.9\%, 13.0\%, and 6.8\% carried ermA, $m s r A, m s r B$, erm $C$, and $\operatorname{erm} B$ genes, respectively. Among clindamycin-resistant MRSA, 83\%, 17\%, 10\%, 4\%, and 2\% carried ermA, erm C, ermB, linA, and $\operatorname{lin} B$ genes, respectively. Among gentamicin- resistant MRSA, 96.8\%, 83.9\%, and 9.7\% carried $\operatorname{aac}\left(6^{\prime}\right) / \operatorname{aph}\left(2^{\prime \prime}\right)$, aph $\left(3^{\prime}\right)-I I I a$, and $\operatorname{ant}\left(4^{\prime}\right)-I a$ genes, respectively. Among tetracycline-resistant MRSA, 6.5\% and 93.5\% carried tet $K$ and tetM genes, respectively. Lastly, among trimethoprim/sulfamethoxazole-resistant MRSA, $13.3 \%$ and $100 \%$ carried $d f r A$ and $d f r G$ genes, respectively. The SCCmec type IV isolates were detected more frequently, whereas the SCCmec type III isolates exhibited higher multidrug resistance. Conclusions: The study data provides information regarding the MRSA resistance profile in South Brazil that is associated with the clinical conditions of patients and can contribute to clinical decision-making.
\end{abstract}

Keywords: Methicillin-resistant Staphylococcus aureus. Healthcare-associated infections. Antimicrobial susceptibility. Resistance genes.

\section{INTRODUCTION}

Antimicrobial resistance poses a significant challenge to modern medicine as well as to the possibility of effective treatment of infectious diseases ${ }^{1}$. Methicillin-resistant Staphylococcus aureus (MRSA) is one of the most frequent causes of community- and healthcare-associated infections (CA-MRSA and HA-MRSA, respectively). A major concern remains owing to higher morbidity and mortality when compared with infections caused by methicillinsusceptible strains (MSSA), along with increased hospitalization and health care costs ${ }^{2}$. MRSA strains pose a threat to public health

\footnotetext{
Corresponding author: MSc. Adriana Medianeira Rossato.

e-mail: adrimfarma@yahoo.com.br

(D) https://orcid.org/0000-0001-5597-0790

Received 4 July 2020

Accepted 12 August 2020
}

owing to their potential for genetic adaptation and remarkable ability to acquire resistance to multiple antimicrobials, along with the implications for the treatment of this pathogen ${ }^{3,4}$.

Methicillin resistance is mediated by the acquisition of genes (mecA or $m e c C$ ) found in the mobile genetic element called staphylococcal cassette chromosome mec (SCCmec), which encodes an altered penicillin-binding protein (PBP2a or PBP2') that confers low affinity for most beta-lactams ${ }^{5,6}$. The SCCmec elements are classified into thirteen different types (SCCmec I-XIII) based on structural organization and genetic content ${ }^{2}$. CA-MRSA strains generally harbor SCCmec type IV or V, and are susceptible to non-beta-lactam antimicrobials. HA-MRSA strains commonly harbor SCCmec types I, II, or III, which contain genes that confer resistance to non-beta-lactam antimicrobials ${ }^{7}$.

Owing to the restricted use of beta-lactams for treating infections caused by MRSA, non-beta-lactam antimicrobials, such as 
aminoglycosides, fluoroquinolones, folate inhibitors, glycopeptides, lincosamides, lipopeptide, macrolides, oxazolidinones, and tetracyclines, are required for the treatment of staphylococcal infections. However, these therapeutic options are reduced when MRSA isolates develop resistance mechanisms to survive in conditions with high concentrations of these antimicrobials ${ }^{4,8,9}$.

Resistance is associated with different molecular mechanisms, as follows: 1) inactivation of antimicrobials by enzymes, such as inactivation of aminoglycosides by aminoglycoside-modifying enzymes (AMEs) (encoded by aac(6')/aph(2"), aph(3')-IIIa, and ant (4')-Ia genes $)^{10}$, trimethoprim by variants of dihydrofolate reductases (DHFRs) $(d f r A \text { and } d f r G)^{11}$, or lincosamide by lincosamide nucleotidyltransferases ( $\operatorname{lin} A$ and $\operatorname{lin} B)^{12,13} ; 2$ ) alterations in ribosomal binding site (ermA ermB, and ermC), which confers resistance to macrolides and lincosamides ${ }^{9,12} ; 3$ ) active efflux pumps, such as those encoded by $m s r A, m s r B$, and tet $K^{12}$, which impart resistance to macrolides, type B streptogramins, and tetracycline, respectively ${ }^{14}$; and 4) ribosomal protection (tetM), that confers resistance to tetracycline ${ }^{14}$. These mechanisms limit the therapeutic options available for the treatment and control of MRSA infections.

The latest data from the Centers for Disease Control and Prevention (CDC) show more than ten thousand deaths caused by MRSA, with high healthcare costs, in the US ${ }^{15}$. In Latin America, the resources for monitoring the epidemiology of MRSA remain limited. Additionally, the true nature and extent of MRSA infections are inadequately known; this indicates that local data collection should be coordinated with effective interventions for making clinical decisions for the control of staphylococcal infections ${ }^{16}$. Considering the importance of global surveillance studies on resistance profiles, along with the current challenges related to the treatment of MRSA infections, this study aimed to evaluate antimicrobial susceptibility and identify the resistance genes in MRSA obtained from hospitals in South Brazil.

\section{METHODS}

\section{Study design and clinical strains}

This cross-sectional observational study was conducted using 217 MRSA isolates obtained between January 2014 and January 2019 (40 in 2014, 49 in 2015, 75 in 2016, 29 in 2017, and 24 in 2018) from hospitals in Porto Alegre in South Brazil. The study was registered under the Institutional Ethics Committee number 2.770.338. The strains were isolated from respiratory tract $(75 ; 34.6 \%)$, blood $(55 ; 25.3 \%)$, skin and soft tissue $(42 ; 19.4 \%)$, bone and connective tissue $(24 ; 11.1 \%)$, and sterile cavity liquid $(12 ; 5.5 \%)$ samples, and from medical devices $(9 ; 4.1 \%)$. The isolates were cryopreserved and stored at $-20{ }^{\circ} \mathrm{C}$ until testing.

\section{Identification of $S$. aureus}

The isolates were identified as $S$. aureus using conventional microbiological methods, such as evaluation of colony morphology on sheep blood agar, Gram staining, catalase activity, production of coagulase, and growth on mannitol salt agar. Methicillin resistance was confirmed by the cefoxitin disk diffusion method and polymerase chain reaction (PCR) for the detection of mecA gene according to Clinical and Laboratory Standard Institute (CLSI) guidelines, $2019^{17}$.

\section{Antimicrobial susceptibility tests}

The susceptibility of isolates to ciprofloxacin $(5 \mu \mathrm{g})$, clindamycin $(2 \mu \mathrm{g})$, erythromycin $(15 \mu \mathrm{g})$, gentamycin $(10 \mu \mathrm{g})$, linezolid $(30 \mu \mathrm{g})$, tetracycline $(30 \mu \mathrm{g})$, and trimethoprim/sulfamethoxazole $(1.25 \mu \mathrm{g} / 23.75 \mu \mathrm{g})$ was determined by the disk diffusion method on Mueller-Hinton agar (Oxoid, Basingstoke, England).

Clindamycin susceptibility was determined using a disk approximation test with erythromycin and clindamycin (D-test). The following resistant phenotypes were identified in the D-test: inducible phenotype (iMLS ${ }_{\mathrm{B}}$ ), when resistant to erythromycin and susceptible to clindamycin with formation of a D-shaped zone, constitutive resistance phenotype $\left(\mathrm{cMLS}_{\mathrm{B}}\right)$ when resistant to both erythromycin and clindamycin, and MS phenotype when resistant to erythromycin and susceptible to clindamycin without formation of a D-shaped zone ${ }^{18}$.

The minimal inhibitory concentration (MIC) of vancomycin was determined using the microdilution method in Mueller-Hinton broth (Oxoid, Basingstoke, England). The results of antimicrobial susceptibility were interpreted according to the CLSI guidelines ${ }^{17}$. The strains obtained from the American Type Culture Collection (ATTC), S. aureus ATCC 25923 and S. aureus ATCC 29213, were used as controls.

\section{Detection of antimicrobial resistance genes}

The detection of genes related to antimicrobial resistance, including (aac(6')/aph(2'), ant(4')-Ia, aph(3')-IIIa, dfrA, dfrG, ermA, ermB, erm $C, \operatorname{lin} A, \operatorname{lin} B, \operatorname{msr} A, m s r B$, tet $K$, and tetM), in MRSA was confirmed by conventional PCR, as previously described, with certain modifications (Table 1) $)^{10,19-23}$.

Bacterial deoxyribonucleic acid was extracted by using Chelex ${ }^{\circledR} 100$ (Bio-Rad, Richmond, CA, USA) and Proteinase K (Sigma-Aldrich, Poole, UK). The PCR reaction contained $0.2 \mathrm{mM}$ of each deoxyribonucleotide triphosphate $(10 \mathrm{mM}), 2 \mathrm{mM}$ of $\mathrm{MgCl}_{2}$ $(50 \mathrm{mM}), 1 \mathrm{X}$ PCR buffer $(10 \mathrm{X}), 0.5 \mu \mathrm{M}$ of forward/reverse primers $(10 \mu \mathrm{M}), 1.5 \mathrm{U}$ of Taq DNA polymerase $(5 \mathrm{U} / \mu \mathrm{L})$, and $1 \mu \mathrm{L}$ of DNA template ina total volume of $25 \mu \mathrm{L}$. Amplifications were performed using a LifePro Thermal Cycler (Hangzhou Bioer Technology Co. Ltd., Hangzhou, China). The PCR amplicons were separated by electrophoresis in a $2.0 \%$ agarose gel (Sigma-Aldrich, USA) and stained with $0.1 \%$ ethidium bromide $(0.4 \mu \mathrm{g} / \mathrm{mL})$.

The PCR-positive controls, S. aureus JCSC 4469 (aac(6')/ aph(2")), S. aureus N315 (ant(4')-Ia), S. aureus JCSC 4488 (aph(3')-IIIa and $d f r G), S$. aureus WIS (dfrA), S. aureus NCTC 10442 (ermA), S. aureus HDE 288 (ermB), S. aureus JCSC 4474 (ermC), S. aureus JCSC 6082 (linA), S. aureus JCSC 2172 (linB), S. aureus NCTC 8325 (msrA and $m s r B$ ), S. aureus 85/2082 (tetK), and $S$. aureus JCSC 6943 (tet $M$ ) were included. A tube containing all components of the PCR mixture, except the template DNA, was used as the negative control.

\section{SCCmec typing}

The SCCmec types I-X were identified by multiplex-PCR, as previously described ${ }^{24}$. The $S$. aureus strains NCTC 10442, N315, 85/2082, JCSC 4474, WIS, HDE 288, JCSC 6082, JCSC 6943, 
TABLE 1: Primer sequences and amplification conditions used to detect resistance genes.

\begin{tabular}{|c|c|c|c|c|}
\hline Target gene & Primer sequence $\left(5^{\prime}-3^{\prime}\right)$ & Amplicon (bp) & Amplification conditions & Ref. \\
\hline $\operatorname{aac}\left(6^{\prime}\right) / a p h\left(2^{\prime \prime}\right)$ & $\begin{array}{c}\text { F: CAG AGC CTT GGG AAG } \\
\text { ATG AAG } \\
\text { R: CCT CGT GTAATT CAT } \\
\text { GTT CTG GC }\end{array}$ & 348 & Pre cycle: $94^{\circ} \mathrm{C}-3 \mathrm{~min}$ & 11 \\
\hline ant(4')-la & $\begin{array}{c}\text { F: CAA ACT GCT AAA TCG } \\
\text { GTA GAA GCC } \\
\text { R: GGAAAG TTG ACC AGA } \\
\text { CAT TAC GAA }\end{array}$ & 294 & $\begin{array}{c}35 \text { cycles: } 94^{\circ} \mathrm{C}-40 \mathrm{~s}, \\
55^{\circ} \mathrm{C}-40 \mathrm{~s}, 72^{\circ} \mathrm{C}-40 \mathrm{~s}\end{array}$ & \\
\hline$a p h\left(3^{\prime}\right)-I I l a$ & $\begin{array}{c}\text { F: GGC TAAAAT GAG AAT } \\
\text { ATC ACC GG } \\
\text { R: CTT TAAAAAATC ATA } \\
\text { CAG CTC GCG }\end{array}$ & 523 & Last cycle: $72^{\circ} \mathrm{C}-2 \min$ & \\
\hline$d f r A$ & $\begin{array}{c}\text { F: CAC TTG TAA TGG CAC } \\
\text { GGAAA } \\
\text { R: CGAATG TGT ATG GTG } \\
\text { GAAAG }\end{array}$ & 270 & $\begin{array}{l}\text { Pre cycle: } 94^{\circ} \mathrm{C}-4 \mathrm{~min} \\
30 \text { cycles: } 94^{\circ} \mathrm{C}-1 \mathrm{~min}, \\
52{ }^{\circ} \mathrm{C}-30 \mathrm{~s}, 72^{\circ} \mathrm{C}-1 \mathrm{~min}\end{array}$ & 19 \\
\hline$d f r G$ & $\begin{array}{c}\text { F: TGC TGC GAT GGA TAA } \\
\text { GAA } \\
\text { R: TGG GCA AAT ACC TCA } \\
\text { TTC C }\end{array}$ & 405 & Last cycle: $72^{\circ} \mathrm{C}-4 \min$ & \\
\hline ermA & $\begin{array}{c}\text { F: TCT AAA AAG CAT GTA } \\
\text { AAA GAA } \\
\text { R: CTT CGA TAG TTT ATT } \\
\text { AAT ATT AGT }\end{array}$ & 645 & $\begin{array}{c}\text { Pre cycle: } 93^{\circ} \mathrm{C}-3 \mathrm{~min} \\
35 \text { cycles: } 93^{\circ} \mathrm{C}-1 \mathrm{~min}, \\
52^{\circ} \mathrm{C}-1 \mathrm{~min}, 72^{\circ} \mathrm{C}-1 \mathrm{~min}\end{array}$ & 20 \\
\hline ermB & $\begin{array}{c}\text { F: GAAAAG GTA CTC AAC } \\
\text { CAAATA } \\
\text { R: AGT AAC GGT ACT TAA } \\
\text { ATT GTT TAC }\end{array}$ & 639 & Last cycle: $72^{\circ} \mathrm{C}-5 \mathrm{~min}$ & \\
\hline ermC & $\begin{array}{c}\text { F: TCA AAA CAT AAT ATA } \\
\text { GAT AAA } \\
\text { R: GCT AAT ATT GTT TAA } \\
\text { ATC GTC AAT }\end{array}$ & 642 & $\begin{array}{c}\text { Pre cycle: } 93^{\circ} \mathrm{C}-3 \mathrm{~min} \\
35 \text { cycles: } 93^{\circ} \mathrm{C}-1 \mathrm{~min}, \\
53^{\circ} \mathrm{C}-1 \mathrm{~min}, 72{ }^{\circ} \mathrm{C}-1 \mathrm{~min} \\
\text { Last cycle: } 72{ }^{\circ} \mathrm{C}-5 \mathrm{~min}\end{array}$ & 20 \\
\hline $\operatorname{lin} A$ & $\begin{array}{c}\text { F: GTA TTA ACT GGA AAA } \\
\text { CAG CAA AG } \\
\text { R: GAG CTT CTT TTG AAA } \\
\text { TAC ATG G }\end{array}$ & 323 & $\begin{array}{l}\text { Pre cycle: } 94^{\circ} \mathrm{C}-5 \mathrm{~min} \\
35 \text { cycles: } 94^{\circ} \mathrm{C}-45 \mathrm{~s},\end{array}$ & 21 \\
\hline $\operatorname{lin} B$ & $\begin{array}{c}\text { F: CCT ACC TAT TGT TTG } \\
\text { TGG AA } \\
\text { R: ATA ACG TTA CTC TCC } \\
\text { TAT TC }\end{array}$ & 925 & $\begin{array}{l}48^{\circ} \mathrm{C} 45 \mathrm{~s}, 72{ }^{\circ} \mathrm{C}-1 \mathrm{~min} \\
\text { Last cycle: } 72{ }^{\circ} \mathrm{C}-5 \mathrm{~min}\end{array}$ & \\
\hline$m s r A$ & $\begin{array}{c}\text { F: GGC ACA ATA AGA GTG } \\
\text { TTT AAA GG } \\
\text { R: AAG TTA TAT CAT GAA } \\
\text { TAG ATT GTC CTG TT }\end{array}$ & 940 & $\begin{array}{l}\text { Pre cycle: } 94^{\circ} \mathrm{C}-5 \mathrm{~min} \\
25 \text { cycles: } 94^{\circ} \mathrm{C}-1 \mathrm{~min},\end{array}$ & 22 \\
\hline$m s r B$ & $\begin{array}{c}\text { F: TAT GAT ATC CAT AAT } \\
\text { AAT TAT CCA ATC } \\
\text { R: AAG TTA TAT CAT GAA } \\
\text { TAG ATT GTC CTG TT }\end{array}$ & 595 & $\begin{array}{l}50^{\circ} \mathrm{C} 1 \mathrm{~min}, 72^{\circ} \mathrm{C}-1 \mathrm{~min} \\
\text { Last cycle: } 72{ }^{\circ} \mathrm{C}-10 \mathrm{~min}\end{array}$ & \\
\hline
\end{tabular}

Continue... 
TABLE 1: Continuation.

\begin{tabular}{|c|c|c|c|c|}
\hline Target gene & Primer sequence (5'-3') & Amplicon (bp) & Amplification conditions & Ref. \\
\hline tetK & $\begin{array}{c}\text { F: CAG CAG ATC CTA CTC } \\
\text { CTT } \\
\text { R: TCG ATA GGA ACA GCA } \\
\text { GTA }\end{array}$ & 168 & $\begin{array}{l}\text { Pre cycle: } 93^{\circ} \mathrm{C}-5 \mathrm{~min} \\
35 \text { cycles: } 93^{\circ} \mathrm{C}-1 \mathrm{~min}, \\
54{ }^{\circ} \mathrm{C} 1 \mathrm{~min}, 72^{\circ} \mathrm{C}-1 \mathrm{~min} \\
\text { Last cycle: } 72{ }^{\circ} \mathrm{C}-10 \mathrm{~min}\end{array}$ & 21 \\
\hline tetM & $\begin{array}{c}\text { F: GTG GAC AAA GGT ACA } \\
\text { ACG AG } \\
\text { R: CGG TAA AGT TCG TCA } \\
\text { CAC AC }\end{array}$ & 405 & $\begin{array}{l}\text { Pre cycle: } 93^{\circ} \mathrm{C}-5 \mathrm{~min} \\
35 \text { cycles: } 93^{\circ} \mathrm{C}-1 \mathrm{~min}, \\
52{ }^{\circ} \mathrm{C} 1 \mathrm{~min}, 72^{\circ} \mathrm{C}-1 \mathrm{~min} \\
\text { Last cycle: } 72{ }^{\circ} \mathrm{C}-10 \mathrm{~min}\end{array}$ & 23 \\
\hline
\end{tabular}

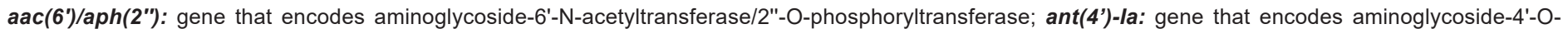

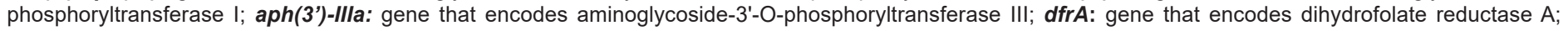

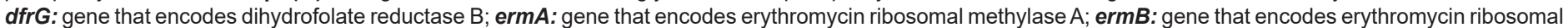

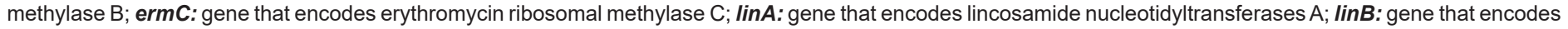

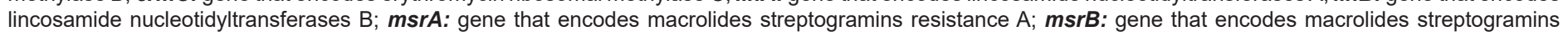
resistance B; tetK: tetracycline resistance protein $\mathrm{K}$; tetM: tetracycline resistance protein $\mathrm{M}$.

and JCSC 6945 were used as the positive controls for the SCCmec types I, II, III, IV, V, VI, VII, IX, and X, respectively. The PCR mixture components without the DNA template were used as negative control.

\section{Statistical analysis}

Statistical analysis was performed using SPSS version 20.0 software (SPSS, Chicago, IL, USA). Chi-square test or Fisher's exact test was performed to analyze the results. $p$ value $<0.05$ was considered statistically significant.

\section{RESULTS}

\section{Antimicrobial susceptibility}

In the antimicrobial susceptibility tests of the MRSA isolates, the highest resistance rates were observed for erythromycin $(74.2 \%$; $161 / 217)$, ciprofloxacin $(64.5 \% ; 140 / 217)$, and clindamycin $(46.1 \%$; $100 / 217)$. Furthermore, $2.3 \%(5 / 217)$ of the isolates exhibited intermediate resistance to erythromycin and $1.4 \%(3 / 217)$ to clindamycin. The overall prevalence of $\mathrm{iMLS}_{\mathrm{B}}, \mathrm{cMLS}_{\mathrm{B}}$, and $\mathrm{MS}_{\mathrm{B}}$ phenotypes was 7.4\% (16/217), 46.1\% (100/217), and 26.3\% (57/217), respectively. Conversely, lower resistance rates were observed against gentamicin $(28.6 \% ; 62 / 217)$, tetracycline $(14.3 \%$; $31 / 217)$, and trimethoprim-sulfamethoxazole $(13.8 \% ; 30 / 217)$. Additionally, 1.8\% (4/217) of the isolates exhibited intermediate resistance to trimethoprim-sulfamethoxazole. All isolates were susceptible to linezolid and vancomycin, with MIC values to vancomycin of $0.25 \mu \mathrm{g} / \mathrm{mL}(41.0 \%$; 89/217), $0.5 \mu \mathrm{g} / \mathrm{mL}(26.3 \%$; 57/217), $0.75 \mu \mathrm{g} / \mathrm{mL}(16.6 \% ; 36 / 217), 1 \mu \mathrm{g} / \mathrm{mL}(13.4 \% ; 29 / 217)$, and $1.5 \mu \mathrm{g} / \mathrm{mL}(2.8 \% ; 6 / 217)$ (Figure 1).

Among the 177 out of the 217 MRSA isolates that exhibited resistance to non-beta-lactam antimicrobials, we observed 17 distinct patterns (P) of antimicrobial resistance (Figure 2), of which 12 were grouped and 5 were singular patterns. The dominant resistance pattern (P1) - erythromycin and ciprofloxacin resistance-was observed in 37 isolates. The fifth pattern of antimicrobial resistance (P5) was identified in 18 isolates that were resistant to six antimicrobials. Furthermore, resistance patterns to five (P6) and four (P2) antimicrobials were observed in 10 and 31 isolates, respectively (Figure 2).

Upon analyzing the prevalence of MRSA resistance among isolates collected in different years, we observed that 93 isolates (42.9\%) exhibited multidrug resistance, i.e., they were resistant to three or more classes of antimicrobial agents, excluding isolates with intermediate resistance. Among them, 32 (34.4\%) exhibited resistance against at least three different classes of antimicrobials, $28(30.1 \%)$ against four classes, 15 (16.1\%) against five classes, and $18(19.4 \%)$ against six classes.

\section{Detection of antimicrobial resistance genes}

The detection of the resistance genes showed that, among erythromycin-resistant MRSA representing the macrolides class, the most frequently encountered gene was $\operatorname{erm} A(86 ; 53.4 \%)$, followed by $\operatorname{msr} A(73 ; 45.3 \%), \operatorname{msr} B(61 ; 37.9 \%)$, erm $C(21 ; 13.0 \%)$, and ermB $(11 ; 6.8 \%) ; 3(1.9 \%)$ isolates tested negative for these genes. In the lincosamides class, among 100 clindamycin-resistant isolates, $83(83 \%)$ harbored erm A, $17(17 \%)$ harbored erm C, $10(10 \%)$ harbored $e r m B, 4(4 \%)$ harbored $\operatorname{lin} A$, and $2(2 \%)$ harbored $\operatorname{lin} B$; $4(4 \%)$ isolates tested negative for these genes. Among gentamicinresistant MRSA, which represented the aminoglycosides class, out of 62 isolates, $60(96.8 \%)$ harbored $\operatorname{aac}\left(6^{\prime}\right) / \operatorname{aph}\left(2^{\prime \prime}\right), 52$ (83.9\%) harbored $\operatorname{aph}\left(3^{\prime}\right)-I I I a$, and 6 (9.7\%) harbored ant(4')-Ia genes. In the tetracyclines class, of the 31 tetracycline-resistant MRSA isolates, 2 (6.5\%) harbored tet $K$ and 29 (93.5\%) harbored tet $M$ genes. Furthermore, in the folate inhibitors class, of the 30 trimethoprim/sulfamethoxazole-resistant MRSA isolates, 4 (13.3\%) harbored $d f r A$ and $30(100 \%)$ harbored $d f r G$ genes.

Among macrolide-resistant MRSA, the most common gene combination was $m s r A+m s r B(27.3 \%)$, followed by erm $A+$ 


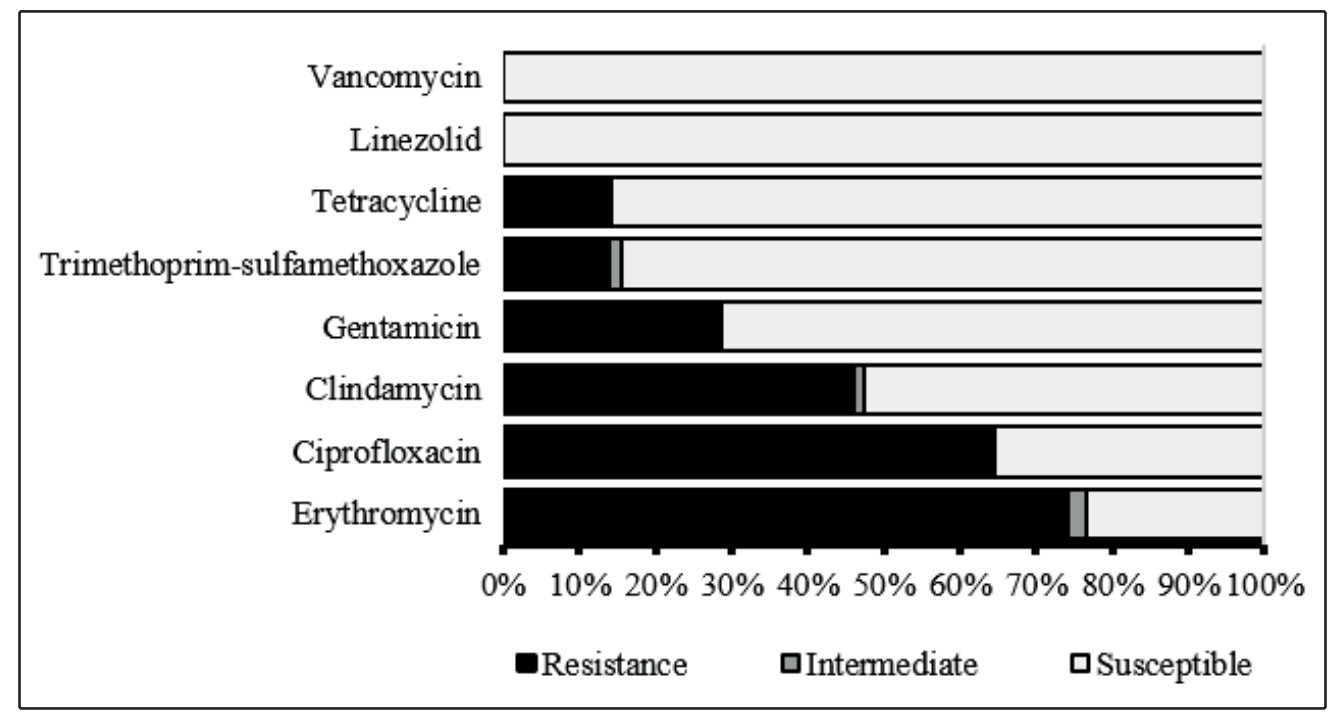

FIGURE 1: Antimicrobial susceptibility of the methicillin-resistant Staphylococcus aureus isolates.

$m s r A+m s r B(5 \%)$, and $\operatorname{erm} A+\operatorname{erm} B+m s r A+m s r B(2.5 \%)$. In the aminoglycosides class, the gene combination $\operatorname{aac}\left(6^{\prime}\right) / \operatorname{aph}\left(2^{\prime \prime}\right)$ $+\operatorname{aph}\left(3^{\prime}\right)$-IIIa $(82.2 \%)$ was more common, followed by aac $\left(6^{\prime}\right) /$ $\operatorname{aph}\left(2^{\prime \prime}\right)+\operatorname{ant}\left(4^{\prime}\right)-I a(4.8 \%)$, and $\operatorname{aac}\left(6^{\prime}\right) / \operatorname{aph}\left(2^{\prime \prime}\right)+\operatorname{aph}\left(3^{\prime}\right)-I I I a+$ $\operatorname{ant}\left(4^{\prime}\right)-I a(1.6 \%)$. Finally, among the fluoroquinolones, lincosamides, and folate inhibitors, the gyrA $\operatorname{grl} A(80.7 \%)$, erm $A+\operatorname{erm} B$ (7.0\%), and $d f r A+d f r G(13.3 \%)$ combinations, respectively, were observed more frequently. The pattern of antimicrobial-resistance gene distribution among resistant MRSA is outlined in Table 2.

\section{SCCmec typing}

The SCCmec type IV (57.1\%) was the most frequent SCCmec type among the MRSA isolates, followed by type III (17.1\%), type I (13.4\%), type II (9.2\%), and type V (1.4\%). Four MRSA isolates were nontypable. Isolates of the MRSA SCCmec types VI, VII, IX, and X were not detected. The antimicrobial resistance distribution pattern with respect to the MRSA SCCmec types is presented in Table 3.

In general, the MRSA SCCmec type III strains exhibited higher multidrug resistance $(\mathrm{p}<0.001)$. In contrast, the MRSA SCCmec type IV strains were more multidrug-susceptible compared to the other SCCmec types $(\mathrm{p}<0.001)$. The MRSA SCCmec type I, type II, and type III strains were more resistant to ciprofloxacin, clindamycin, and erythromycin than the MRSA SCCmec type IV strains, which were significantly susceptible to the same antimicrobials $(\mathrm{p}<0.001)$. Similarly, the MRSA SCCmec type I and type II strains were more resistant to these antimicrobials than MRSA SCCmec type V strains, which were significantly susceptible $(\mathrm{p}<0.001)$. In addition, the MRSA SCCmec type I and type III strains were more resistant to gentamycin than the MRSA SCCmec type IV and type V strains, that were susceptible to the same antimicrobial $(\mathrm{p}<0.001)$. Lastly, the MRSA SCCmec type III strains were more resistant to trimethoprim-sulfamethoxazole and tetracycline than most MRSA SCCmec type I, type II, and type IV strains, which were susceptible to the same antimicrobials $(\mathrm{p}<0.001)$.

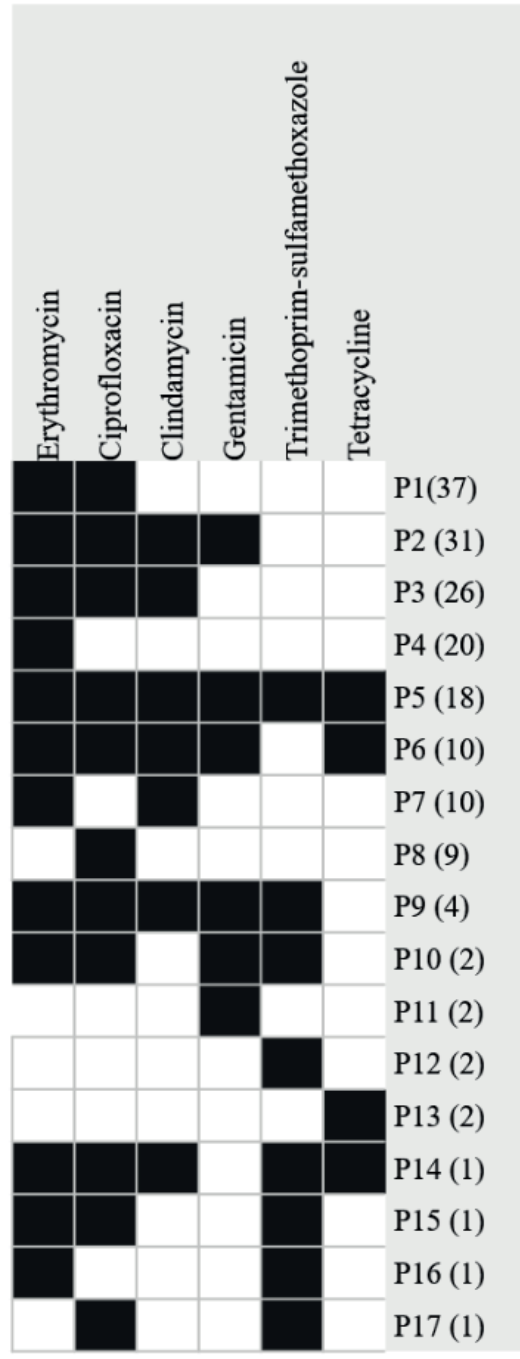

FIGURE 2: Heat map of antimicrobial resistance patterns among 217 methicillin-resistant Staphylococcus aureus isolates. 
TABLE 2: Distribution of antimicrobial resistance genes.

\begin{tabular}{|c|c|c|}
\hline Antimicrobial classes & Number of resistant MRSA isolates (\%) & Resistance genes (\%) \\
\hline Macrolides & Erythromycin 161 (74.2) & $\begin{array}{l}\text { ermA } 64(39.7) \\
\text { erm } C 14(8.7) \\
m s r A 10(6.2) \\
m s r B 2(1.2) \\
\text { ermA + ermB } 2(1.2) \\
\text { ermA + erm } 1(0.6) \\
\text { ermA + msrA } 2(1.2) \\
m s r A+m s r B 44(27.3) \\
\text { ermA + ermB }+ \text { emrC } 2(1.2) \\
\text { ermA + ermB + msrA } 1(0.6) \\
\text { ermA + msrA + msrB } 8(5.0) \\
\text { emr }+m s r A+m s r B 2(1.2) \\
\text { ermA + ermB + emrC + msrA } 1(0.6) \\
\text { ermA + ermB + msrA + msrB } 4(2.5) \\
\text { ermA + ermB + emrC + msrA + msrB } 1(0.6) \\
\text { Unknown } 3(1.9)\end{array}$ \\
\hline Lincosamides & Clindamycin 100 (46.1) & $\begin{array}{l}\text { ermA } 68(68.0) \\
\text { erm } C 13(13.0) \\
\text { ermA + ermB } 7(7.0) \\
\text { ermA + erm } 1(1.0) \\
\text { ermA + ermB }+ \text { erm } C 3(3.0) \\
\text { ermA + linA } 2(2.0) \\
\text { erm }+\operatorname{lin} A+\operatorname{lin} B 2(2.0) \\
\text { Unknown } 4(4.0)\end{array}$ \\
\hline Aminoglycosides & Gentamycin 62 (28.6) & $\begin{array}{l}\operatorname{ant}\left(4^{\prime}\right)-\operatorname{la} 2(3.2) \\
\operatorname{aac}\left(6^{\prime}\right) / \operatorname{aph}\left(2^{\prime \prime}\right) 5(8.1) \\
\operatorname{aac}\left(6^{\prime}\right) / \operatorname{aph}\left(2^{\prime \prime}\right)+\operatorname{ant}\left(4^{\prime}\right)-\operatorname{la} 3(4.8) \\
\operatorname{aac}\left(6^{\prime}\right) / \operatorname{aph}\left(2^{\prime \prime}\right)+\operatorname{aph}\left(3^{\prime}\right)-I I l a 51(82.2) \\
\operatorname{aac}\left(6^{\prime}\right) / \operatorname{aph}\left(2^{\prime \prime}\right)+\operatorname{aph}\left(3^{\prime}\right)-I I l a+\operatorname{ant}\left(4^{\prime}\right)-\operatorname{la} 1(1.6)\end{array}$ \\
\hline Folate inhibitors & Trimethoprim-sulfamethoxazole 30 (13.8) & $\begin{array}{l}d f r G 26(86.7) \\
d f r A+d f r G 4(13.3)\end{array}$ \\
\hline Tetracyclines & Tetracycline 31 (14.3) & $\begin{array}{l}\text { tetK } 2(6.5) \\
\text { tetM } 29(93.5)\end{array}$ \\
\hline
\end{tabular}

aac(6')/aph(2'): gene that encodes aminoglycoside-6'-N-acetyltransferase/2"-O-phosphoryltransferase; ant(4')-la: gene that encodes aminoglycoside-4'-Ophosphoryltransferase I; aph(3')-IIla: gene that encodes aminoglycoside-3'-O-phosphoryltransferase III; dfrA: gene that encodes dihydrofolate reductase A; dfrG: gene that encodes dihydrofolate reductase B; ermA: gene that encodes erythromycin ribosomal methylase $A$; ermB: gene that encodes erythromycin ribosomal methylase B; erm C: gene that encodes erythromycin ribosomal methylase C; linA: gene that encodes lincosamide nucleotidyltransferases A; linB: gene that encodes lincosamide nucleotidyltransferases B; $\boldsymbol{m s} \boldsymbol{A}$ : gene that encodes macrolides streptogramins resistance A; $\boldsymbol{m s r} B$ : gene that encodes macrolides streptogramins resistance $\mathrm{B}$; tetK: tetracycline resistance protein $\mathrm{K}$; tetM: tetracycline resistance protein $\mathrm{M}$.

TABLE 3: Antimicrobial resistance distribution between the methicillin-resistant Staphylococcus aureus SCCmec types.

\begin{tabular}{|c|c|c|c|c|c|c|}
\hline \multirow{2}{*}{ Antimicrobials } & \multicolumn{6}{|c|}{ SCCmec types } \\
\hline & $I(n=29)$ & II $(n=20)$ & III $(n=37)$ & IV $(n=124)$ & $V(n=3)$ & NT $(n=4)$ \\
\hline Erythromycin & $28(96.6 \%)^{c, d}$ & $20(100 \%)^{c, d}$ & $33(89.2 \%)^{a, c}$ & $75(60.5 \%)^{b}$ & $1(33.3 \%)$ & $4(100 \%)$ \\
\hline Ciprofloxacin & $28(96.6 \%)^{c, d}$ & $20(100 \%)^{c, d}$ & $33(89.2 \%)^{a, c}$ & $55(44.0 \%)^{b}$ & - & $4(100 \%)$ \\
\hline Clindamycin & $28(96.6 \%)^{c, d}$ & $19(95.0 \%)^{c, d}$ & $32(86.5 \%)^{a, c}$ & $18(14.5 \%)^{b}$ & $1(33.3 \%)$ & $2(50.0 \%)$ \\
\hline Gentamycin & $24(82.8 \%)^{\mathrm{e}}$ & $2(10.0 \%)$ & $29(78.4 \%)^{a, e}$ & $3(2.4 \%)^{b}$ & - & $4(100 \%)$ \\
\hline Tetracycline & - & $2(10.0 \%)$ & $26(70.3 \%)^{a, f}$ & $2(1.6 \%)^{b}$ & $1(33.3 \%)$ & - \\
\hline $\begin{array}{c}\text { Trimethoprim- } \\
\text { sulfamethoxazole }\end{array}$ & - & $1(5.3 \%)$ & $20(54.1 \%)^{a, f}$ & $5(4.0 \%)^{b}$ & - & $4(100 \%)$ \\
\hline
\end{tabular}

NT: non-typable. Data are indicated by the number of isolates (\%).

${ }^{a}$ MRSA SCCmec type III was more multidrug-resistant $(p<0.001)$.

${ }^{\mathrm{b}}$ MRSA SCCmec type IV was more multidrug-susceptible $(p<0.001)$.

${ }^{\mathrm{C}}$ MRSA SCCmec types I, II, and III were more resistant to erythromycin, ciprofloxacin, and clindamycin, than MRSA SCCmec type IV ( $p<0.001$ ).

${ }^{d}$ MRSA SCCmec types I and II were more resistant to erythromycin, ciprofloxacin, and clindamycin, than MRSA SCCmec type V (p<0.001).

e MRSA SCCmec types I and III were more resistant to gentamycin than MRSA SCCmec types IV and V $(p<0.001)$.

${ }^{\mathrm{f}}$ MRSA SCCmec type III was more resistant to trimethoprim-sulfamethoxazole and tetracycline than most MRSA SCCmec types I, II, and IV ( $p<0.001$ ) 


\section{DISCUSSION}

In the last two decades, the proportion of MRSA has increased worldwide ${ }^{18}$. At present, MRSA may be considered the first class of multidrug-resistant (MDR) pathogens, based on the emergence of the concomitant resistance of MRSA to multiple commonly used non-beta-lactam antimicrobials (for e.g., aminoglycosides, macrolides, fluoroquinolones, and tetracycline $)^{25-27}$.

In the present study, 177 MRSA (81.6\%) isolates exhibited resistance to at least one of the non-beta-lactam antimicrobials tested, which is indicative of the high resistance rates for erythromycin, ciprofloxacin, and clindamycin antimicrobials. These resistance rates are in accordance with findings from other studies in southern ${ }^{28-30}$ and other regions of Brazil ${ }^{31,32}$.

Erythromycin and clindamycin are members of the macrolidelincosamide-streptogramin $\mathrm{B}\left(\mathrm{MLS}_{\mathrm{B}}\right)$ family, which exhibit excellent potential in MRSA infections and are frequently used to treat staphylococcal skin and soft tissue infections (SSTIs) ${ }^{12,13,33}$. erm gene-mediated resistance to $\mathrm{MLS}_{\mathrm{B}}$ can be expressed in constitutive (cMLS $_{\mathrm{B}}$ phenotype) or inducible (iMLS B $_{\mathrm{B}}$ phenotype) forms ${ }^{18,34,35}$. In this study, the prevalence of $\mathrm{cMLS}_{\mathrm{B}}$ was $38.7 \%$, whereas other studies conducted in Brazil reported $\mathrm{cMLS}_{\mathrm{B}}$ resistance of approximately $14.3 \%$ and $68.2 \%{ }^{34,36}$.

Besides, an important issue in the application of clindamycin is the inducible resistance owing to the presence of methylase synthesis inducers, such as erythromycin, which leads to increased failure in clinical therapeutic applications ${ }^{18,34}$. In this study, a prevalence of the iMLS $\mathrm{B}_{\mathrm{B}}$ phenotype was observed among $7.4 \%$ of the MRSA isolates tested, which is consistent with that reported by Bottega et al $(7.9 \%)^{36}$, and higher than that reported by Pereira et al. $(4.5 \%)^{34}$, with both studies conducted in Brazil.

The distribution of resistance genes detected in this analysis demonstrates that ermA $(39.6 \%)$ was the predominant gene compared to erm $C(9.7 \%)$ and ermB $(5.1 \%)$. In contrast, in another Brazilian study, it was shown that ermC $(38.6 \%$; 17/44) was identified more frequently than ermA $(9.1 \% ; 4 / 44)^{9,37-41}$. In this study, one MRSA isolate carried both ermA and ermC, which encode proteins for erythromycin and clindamycin resistance. The coexistence of these genes in MRSA isolates was also observed in other studies ${ }^{9,34,42}$.

Among the $m s r$ genes, $m s r A$, which confers resistance to macrolides and type B streptogramins, had the highest prevalence (33.6\%), followed by $m s r B(28.1 \%)$. In contrast to the data from this study, resistance via efflux pumps (associated with $m s r A / m s r B$ ) was not detected in MRSA in a study by Khodabandeh et al. ${ }^{9}$, whereas Sarrou et al ${ }^{42}$ detected only $m s r A$ in MRSA isolates. The $m s r A+m s r B$ gene combination of resistance was more prevalent in this study. Additionally, the erm $A+\operatorname{erm} B+m s r A+m s r B$ gene combination was detected in four isolates. These findings are consistent with those of a study on the development of genotype prevalence in Serbia performed by Misic et al. ${ }^{43}$, in which similar results of genetic combinations were reported.

The predominance of MRSA in SSTIs and their treatment using ciprofloxacin consequently led to an increase in fluoroquinolone resistance, and thereby limited the therapeutic use of this class of antimicrobials ${ }^{44,45}$. In this study, $64.5 \%$ of MRSA isolates were resistant to ciprofloxacin. In two studies with MRSA isolated from seven hospitals in Rio de Janeiro, Brazil, resistance to fluoroquinolones varied between $60.6 \%$ and $93 \% \%^{32,46}$ while in another study that used isolates collected from three cities in a southern Brazilian state, $79 \%$ of the MRSA isolates exhibited fluoroquinolone resistance ${ }^{30}$.

In this study, the rates for trimethoprim-sulfamethoxazole, tetracycline, and gentamicin resistance were observed to be low, which was consistent with recent reports from other studies conducted in Brazil ${ }^{29,31}$.

Trimethoprim-sulfamethoxazole (folate inhibitors class) is an alternative choice for the treatment of mild to moderate SSTIs caused by MRSA, based on the results of susceptibility tests ${ }^{4,11}$. The presence of the $d f r G$ gene was confirmed in $86.7 \%$ of MRSA isolates, and the association between $d f r A$ and $d f r G$ was confirmed in $13.3 \%$. Moreover, Coelho et al. ${ }^{47}$ compared $S$. aureus isolates collected from Portuguese-speaking African countries with a Brazilian MRSA clone (ST239-III), and observed 78\% prevalence of the $d f r G$ gene, $19 \%$ of the $d f r A$ gene, or $3 \%$ of both.

Aminoglycosides constitute an important class of antimicrobials, especially for the treatment of complicated staphylococcal infections synergistically with glycopeptides or beta-lactams ${ }^{48}$. In an attempt to confirm the resistance to aminoglycosides in MRSA, the presence of genetic elements that encode AMEs was evaluated, with $82.2 \%$ of MRSA exhibiting the $\operatorname{aac}\left(6^{\prime}\right) / a p h\left(2^{\prime \prime}\right) / a p h\left(3^{\prime}\right)$-III a gene association. Previous reports showed the presence of this association among 9\% and $55.5 \%$ isolates ${ }^{10,49}$. Tetracycline has exhibited clinical efficacy in cases of community-associated MRSA SSTIs ${ }^{50}$. In this study, the presence of tet $K$ and tet $M$ genes was observed in $6.5 \%$ and $93.5 \%$ of isolates, respectively.

In contrast, all the MRSA isolates tested were susceptible to linezolid and vancomycin, as observed in other Brazilian studies ${ }^{51-54}$. Currently, resistance to oxazolidinones (including linezolid) among $S$. aureus is rare, whereas prolonged exposure to vancomycin leads to the emergence of MRSA with reduced vancomycin susceptibility, and the strains are categorized as vancomycin-intermediate S. aureus (VISA) and heterogeneous VISA (hVISA) ${ }^{55}$, as reported in other studies conducted in Brazil ${ }^{28-56}$. Nevertheless, vancomycin remains the first-line therapeutic choice for the treatment of invasive MRSA infections, such as bacteremia, pneumonia, and osteoarticular infection; linezolid is an alternative for the treatment of invasive hVISA and VISA infections ${ }^{3,4}$.

SCCmec typing provides useful information regarding resistance to antimicrobials and the origin of $S$. aureus strains ${ }^{57}$. In our study, SCCmec IV and III were the most common SCCmec types, which is consistent with findings reported earlier ${ }^{57-59}$. In addition, the MRSA SCCmec type III strains exhibited higher multidrug resistance, whereas the MRSA SCCmec type IV were more multidrugsusceptible compared to other SCCmec types. Previous studies have shown that HA-MRSA isolates generally contain SCCmec types I, II, or III, which confer resistance to non-beta-lactam antimicrobials and tend to lead to multidrug-resistance ${ }^{7,60}$. Furthermore, SCCmec type IV was most commonly detected among the MRSA isolates, 
and this characteristic is often observed in CA-MRSA strains, which are generally susceptible to non-beta-lactam antimicrobials and harbor SCCmec types IV or V.

Our study has certain limitations. First, we were unable to test other therapeutic options, such as ceftaroline, daptomycin, and tigecycline. Second, we could not determine the MICs for all the antimicrobials tested. Despite these limitations, the HA-MRSA isolates in our setting were confirmed to be MDR, which limits the therapeutic options available for the treatment of infections caused by such MRSA isolates. Third, the isolates included in this study were not genotyped to assess the clonality. In this study, high erythromycin, ciprofloxacin, and clindamycin resistance rates were observed, and the isolates exhibited considerable diversity of genes related to non-beta-lactam resistance mechanisms in MRSA strains. This indicates the urgency for the development of alternative therapeutic options. Despite the fact that multidrug resistance is increasing in the study setting, linezolid and vancomycin appear to be effective therapeutic options for MDR-MRSA strains. The study data provide information regarding the resistance profile of MRSA isolates from South Brazil, and along with data on the clinical conditions of the patients, it can contribute to the clinical decision-making process.

\section{ACKNOWLEDGMENTS}

We thank the Postgraduate Program in Health Sciences of Porto Alegre (PPGCS) of the Federal University of Health Sciences of Porto Alegre (UFCSPA).

\section{FINANCIAL SUPPORT}

We received financial support from the Research Foundation of the State of Rio Grande do Sul (FAPERGS - 02/2017) and National Council for Scientific and Technological Development (CNPq - 14/2014).

\section{AUTHORS' CONTRIBUTIONS}

AMR: conception and planning of the study; obtaining, analyzing and interpreting data; statistical analysis; elaboration and writing of the manuscript; effective participation in research orientation; critical review of the literature and the manuscript; approval of the final version of the manuscript. MPB: elaboration and writing of the manuscript; critical review of the literature and the manuscript; approval of the final version of the manuscript. LLR: planning of the study; approval of the final version of the manuscript. KCR: critical review of the literature and the manuscript; approval of the final version of the manuscript. CAGD: critical review of the manuscript; approval of the final version of the manuscript. PAdA: conception and planning of the study; effective participation in research orientation; critical review of the literature and the manuscript; approval of the final version of the manuscript.

\section{CONFLICTS OF INTEREST}

The authors declare no conflicts of interest.

\section{REFERENCES}

1. World Health Organization (WHO). Global Action Plan on Antimicrobial Resistance. Technical Report. Geneva: WHO; 2015. 28 p.
2. Lakhundi S, Zhang K. Methicillin-resistant Staphylococcus aureus: molecular characterization, evolution, and epidemiology. Clin Micr Rev. 2018;31(4):e00020-18.

3. Turner N, Sharma-Kuinkel BK, Maskarinec SA, Eichenberger EM, Shah PP, Carugati M, et al. Methicillin-resistant Staphylococcus aureus: an overview of basic and clinical research. Nat Rev Mic. 2019;17:203-18.

4. Lee S, Lencastre H, Garau J, Kluytmans J, Malhotra-Kumar S, Peschel A, et al. Methicillin-resistant Staphylococcus aureus. Nat Rev Dis Primers. 2018;4:18033.

5. Geisinger E, Isberg RR. Interplay between antibiotic resistance and virulence during disease promoted by multidrug-resistant bacteria. Jour of Infec Dis. 2017;215(S1):S9-S17.

6. Costa T, de Oliveira C, Chambers H, Chatterjee S. PBP4: A New Perspective on Staphylococcus aureus $\beta$-Lactam Resistance. Microo. 2018;6(3):57.

7. Kateete, DP, Bwanga F, Seni J, Mayanja R, Kigozi E, Mujuni B, et al. CA-MRSA and HA-MRSA coexist in community and hospital settings in Uganda. Antim Resis Infect Control. 2019;8:94.

8. Kashyap R, Shah A, Dutt TPMW, Ahdal J, Jain R. Treatments and limitations for methicillin-resistant Staphylococcus aureus: A review of current literature. Jour Clin Infec Dis Wor. 2019;9(1):1-10.

9. Khodabandeh M, Mohammadi M, Abdolsalehi MR, Alvandimanesh A, Gholami M, Bibalan MH, et al. Analysis of resistance to macrolidelincosamide-streptogramin B among mecA-positive Staphylococcus aureus isolates. Osong Pub Heal Res Pers. 2019;10(1):25-31.

10. Khosravi AD, Jenabi A. Montazeri EA. Distribution of genes encoding resistance to aminoglycoside modifying enzymes in methicillinresistant Staphylococcus aureus (MRSA) strains. Kaoh Jour Med Scie. 2017;33(12):587-93.

11. Nurjadi D, Olalekan AO, Layer F, Shittu AO, Alabi A, Ghebremedhin B, et al. Emergence of trimethoprim resistance gene dfrG in Staphylococcus aureus causing human infection and colonization in sub-Saharan Africa and its import to Europe. Jour Antim Chem. 2014;69:2361-68.

12. Razeghi M, Saffarian P, Goudarzi M. Incidence of inducible clindamycin resistance and antibacterial resistance genes variability in clinical Staphylococcus aureus strains: A two-year multicenter study in Tehran, Iran. Gen Rep. 2019;16:100411.

13. Khashei R, Malekzadegan Y, Ebrahim-Saraie HS, Razavi Z. Phenotypic and genotypic characterization of macrolide, lincosamide and streptogramin B resistance among clinical isolates of staphylococci in southwest of Iran. BMC Res Notes. 2018;11711.

14. Thaker M, Spanogiannopoulos P, Wright GD. The tetracycline resistome. Cel Mol Lif Scie. 2010;67:419-31.

15. Centers for Disease Control and Prevention (CDC). Antibiotic Resistance Threats in the United States, 2019. U.S. Department of Health and Human Services. Atlanta: CDC; 2019. 115 p.

16. Mejía C, Zurita J, Guzmán-Blanco M. Epidemiology and surveillance of methicillin-resistant Staphylococcus aureus in Latin America. Braz Jour Infec Dis. 2010;14(S2):S79-S86.

17. Clinical and Laboratory Standards Institute (CLSI). Performance Standarts for Antimicrobial Susceptibility Testing. 29th ed. Wayne: PA; 2019. $25 \mathrm{p}$.

18. Adhikari RP, Shrestha S, Barakoti A, Amatya R. Inducible clindamycin and methicillin resistant Staphylococcus aureus in a tertiary care hospital, Kathmandu, Nepal. BMC Infec Dis. 2017;17:483.

19. Sousa VS, Silva, APS, Sorenson L, Paschoal RP, Rabello RF, Campana EL, et al. Staphylococcus saprophyticus recovered from humans, food, and recreational waters in Rio de Janeiro, Brazil. Intern Jour Microb. 


\section{$2017 ; 4287547$.}

20. Sutcliffe J, Grebe T, Tait-Kamradt A, Wondrack L. Detection of erythromycin-resistant determinants by PCR. Antim Agen Chem. 1996;40(11):2562-66.

21. Lina G, Quaglia A, Reverdy M, Leclercq R, Vandernesch F, Etienne J. Distribution of genes encoding resistance to macrolides, lincosamides, and streptogramins among staphylococci. Antim Agen Chem. 1999;43(5):1062-66.

22. Yıldız Ö, Çoban AY, Şener AG, Coşkuner SA, Bayramoğlu G, Güdücüoğlu $H$, et al. Antimicrobial susceptibility and resistance mechanisms of methicillin resistant Staphylococcus aureus isolated from 12 Hospitals in Turkey. Ann Clin Microb Antim. 2014;13:44.

23. Warsa UC, Nonoyama M, Ida T, Okamoto R, Okubo T, Shimauchi C, Kuga A, et al. Detection of tet(K) and tet(M) in Staphylococcus aureus of Asian Countries by the Polymerase Chain Reaction. Jour Antib. 1996;49(11):1127-32.

24. Lawung R, Chuong LV, Cherdtrakulkiat R, Srisarin A, Prachayasittikul $\mathrm{V}$. Revelation of staphylococcal cassette chromosome mec types in methicillin-resistant Staphylococcus aureus isolates from Thailand and Vietnam. J Microb Meth. 2014;107:8-12.

25. Boucher HW, Talbot GH, Bradley JS, Edwards JE, Gilbert D, Rice LB, et al. Bad bugs, no drugs: no ESKAPE! An update from the Infectious Diseases Society of America. Clin Infec Dis. 2009;48(1):1-12.

26. Kaur DC, Chate SS. Study of antibiotic resistance pattern in methicillin resistant Staphylococcus aureus with special reference to newer antibiotic. Jour Glob Infec Dis. 2015:7(2):78-84.

27. van Duin D, Paterson DL. Multidrug-resistant bacteria in the community: Trends and lessons learned. Infec Dis Clin Nort Amer. 2016;30(2):377-90.

28. Oliveira CF, Morey AT, Santos JP, Gomes LVP, Cardoso JD, PingeFilho $\mathrm{P}$, et al. Molecular and phenotypic characteristics of methicillinresistant Staphylococcus aureus isolated from hospitalized patients. Jour Infec Dev Coun. 2015;9(7):743-51.

29. Rossato AM, Reiter KC, Soares RO, Paim TGS, Sambrano GE, D’Azevedo PA. Características moleculares de Staphylococcus aureus suscetível à vancomicina poderia ajudar a prever falhas no tratamento devido à reduzida suscetibilidade à vancomicina. Rev Epid Cont Infec. 2018;8(4):422-27.

30. Silveira ACO, Cunha GR, Caierão J, Cordova CM, d'Azevedo PA. MRSA from Santa Catarina State, Southern Brazil: Intriguing epidemiological differences compared to other Brazilian regions. Braz Jour Infec Dis. 2015;19(4):384-89.

31. Bride LL, Pereira MF, Barbosa MC, Silva NC, Klein NM, Nascimento $\mathrm{TC}$, et al. Differences in resistance profiles and virulence genes among methicillin-resistant and methicillin-susceptible Staphylococcus aureus of different lineages at a public tertiary hospital. Rev Soc Bras Med Trop. 2019;52:e20190095.

32. Caboclo RMF, Cavalcante FS, Iorio NLP, Schuenck RP, Olendzki AN, Felix MJ, et al. Methicillin-resistant Staphylococcus aureus in Rio de Janeiro hospitals: Dissemination of the USA400/ST1 and USA800/ST5 SCCmec type IV and USA100/ST5 SCCmec type II lineages in a public institution and polyclonal presence in a private one. Amer Jour Infec Cont. 2013;41(3):e21-6.

33. Lee S, Lencastre H, Garau J, Kluytmans J, Malhotra-Kumar S, Peschel A, et al. Methicillin-resistant Staphylococcus aureus. Nat Rev Dis Prim. 2018;4:18033.

34. Pereira, JNP, Rabelo MA, Lima JLC, Neto AMB, Lopes ACS, Maciel MAV. Phenotypic and molecular characterization of resistance to macrolides, lincosamides and type B streptogramin of clinical isolates of Staphylococcus spp. of a university hospital in Recife, Pernambuco, Brazil. Braz Jour Infec Dis. 2016;20(3):276-81.

35. Yao W, Xu G, Li D, Bai B, Wang H, Cheng H, et al. Staphylococcus aureus with an erm-mediated constitutive macrolide-lincosamidestreptogramin B resistance phenotype has reduced susceptibility to the new ketolide, solithromycin. BMC Infec Dis. 2019;19:175.

36. Bottega A, Rodrigues MA, Carvalho FA, Wagner TF, Leal IAS, Santos SO, et al. Evaluation of constitutive and inducible resistance to clindamycin in clinical samples of Staphylococcus aureus from a tertiary hospital. Rev Soc Bras Med Trop. 2014;47(5):589-92.

37. Abdullahi N, Iregbu K. Methicillin-Resistant Staphylococcus aureus in a Central Nigeria Tertiary Hospital. Ann Trop Path. 2018;9(1):6-10.

38. Gitau W, Masika M, Musyoki M, Museve B, Mutwiri T. Antimicrobial susceptibility pattern of Staphylococcus aureus isolates from clinical specimens at Kenyatta National Hospital. BMC Res Notes. 2018;11(1):226.

39. Kim HJ, Choi Q, Kwon GC, Koo SH. Molecular epidemiology and virulence factors of methicillin-resistant Staphylococcus aureus isolated from patients with bacteremia. Jour Clin Lab Anal. 2019;00:e23077.

40. Son NT, Huong VTT, Lien VTK, Nga DTQ, Au TTH, Nga TT, et al. First report on multidrug-resistant methicillin-resistant Staphylococcus aureus isolates in children admitted to tertiary hospitals in Vietnam. Jour Microb Biot. 2019;29(9):1460-69.

41. Peng H, Liu D, Ma Y, Gao W. Comparison of community- and healthcareassociated methicillin-resistant Staphylococcus aureus isolates at a Chinese tertiary hospital, 2012-2017. Scie Rep. 2018;8:17916.

42. Sarrou S, Malli E, Tsilipounidaki K, Florou Z, Medvecky M, Skoulakis A, et al. MLSB-resistant Staphylococcus aureus in central Greece: Rate of resistance and molecular characterization. Microb Drug Res. 2019;25(4):543-50.

43. Mišić M, Čukić J, Vidanović D, Šekler M, Matić S, Vukašinović M, et al. Prevalence of genotypes that determine resistance of staphylococci to macrolides and lincosamides in Serbia. Front Pub Heal. 2017;5:1-8.

44. Gajdács M. The continuing threat of methicillin-resistant Staphylococcus aureus. Antib. 2019;8(2):52.

45. Jones TM, Johnson SW, Dimondi VP, Wilson DT. Focus on JNJ-Q2, a novel fluoroquinolone, for the management of community-acquired bacterial pneumonia and acute bacterial skin and skin structure infections. Infec Drug Res. 2016;9:119-28.

46. Zuma AVP, Lima DF, Assef APDAC, Marques EA, Leão RS. Molecular characterization of methicillin-resistant Staphylococcus aureus isolated from blood in Rio de Janeiro displaying susceptibility profiles to non- $\beta$ lactam antibiotics. Braz Jour Microb. 2017;48(2):237-41.

47. Coelho C, de Lencastre H, Aires-de-Sousa M. Frequent occurrence of trimethoprim-sulfamethoxazole hetero-resistant Staphylococcus aureus isolates in different African countries. Eur Jour Clin Microb Infec Dis. 2017;36:1243-52.

48. Ida T, Okamoto R, Shimauchi C, Okubo $T$, Kuga A, Inoue $M$. Identification of aminoglycoside-modifying enzymes by susceptibility testing: Epidemiology of methicillin-resistant Staphylococcus aureus in Japan. Jour Clin Microb. 2011;39(9):3115-21.

49. ElFeky DS, Awad AR, Elshobaky MA, Elawady BA. Effect of ceftaroline, vancomycin, gentamicin, macrolides, and ciprofloxacin against methicillin-resistant Staphylococcus aureus isolates: An in vitro study. Surg Infec. 2020;21(2):150-2.

50. Loewen K, Schreiber Y, Kirlew M, Bocking N. Community-associated methicillin-resistant Staphylococcus aureus infection. Can Fam Phys. 2017;63(7):512-20. 
51. Paternina-dela-Ossa R, Prado SI, Cervi MC, Lima DAFS, Martinez R, Bellissimo-Rodrigues F. Is community-associated methicillin-resistant Staphylococcus aureus (CA-MRSA) an emerging pathogen among children in Brazil? Braz Jour Infec Dis. 2018;22(5):371-76.

52. Miranda OP, Silva-Carvalho MC, Ribeiro A, Portela F, Cordeiro RP, Caetano N, et al. Emergence in Brazil of methicillin-resistant Staphylococcus aureus isolates carrying SCCmec IV that are related genetically to the USA800 clone. Clin Microb Infec. 2007;13(12):1165-72.

53. Becker AP, Santos O, Castrucci FM, Dias C, d'Azevedo PA. First report of methicillin-resistant Staphylococcus aureus Cordobes/ Chilean clone involved in nosocomial infections in Brazil. Epid Infec. 2012;140(8):1372-75.

54. Gales AC, Sader HS, Ribeiro J, Zoccoli C, Barth A, Pignatari AC. Antimicrobial susceptibility of Gram-positive bacteria isolated in Brazilian hospitals participating in the SENTRY Program (2005-2008). Braz Jour Infec Dis. 2009;13(2):90-8.

55. Watkins RR, Holubar M, David MZ. Antimicrobial resistance in methicillin-resistant Staphylococcus aureus to newer antimicrobial agents. Antim Ag Chem. 2019;63(12):e01216-19.
56. Soares MJS, da Silva-Carvalho MC, Ferreira-Carvalho BT, Figueiredo AM. Spread of methicillin-resistant Staphylococcus aureus belonging to the Brazilian epidemic clone in a general hospital and emergence of hetergenous resistance to glycopeptide antibiotics among these isolates. Jour Hosp Infec. 2000;44(4):301-8.

57. Hashemizadeh Z, Hadi N, Mohebi S, Kalantar-Neyestanaki D, Bazargani, A. Characterization of SCCmec, spa types and multi drug resistant of methicillinresistant Staphylococcus aureus isolates among inpatients and outpatients in a referral hospital in Shiraz, Iran. BMC Res Notes. 2019;12(1):614.

58. ul Bashir Y. SCCmec type IV and V methicillin resistant Staphylococcus aureus intrusion in healthcare settings. Am J Clin Microbiol Antimicrob. 2019;2(1):1032.

59. Sit, PS, Teh CSJ, Idris N, Ponnampalavanar S. Methicillin-resistant Staphylococcus aureus (MRSA) bacteremia: Correlations between clinical, phenotypic, genotypic characteristics and mortality in a tertiary teaching hospital in Malaysia. Infect Genet and Evol. 2018;59:132-41.

60. Kong EF, Johnson JK, Jabra-Rizk MA. Community-associated methicillin-resistant Staphylococcus aureus: An enemy amidst us. PLoS Path. 2016;12(10):e1005837. 